The University of San Francisco

USF Scholarship: a digital repository @ Gleeson Library |

Geschke Center

Philosophy

College of Arts and Sciences

2002

\title{
A Critique of the U.S. Genetic Privacy Act
}

Thomas A. Cavanaugh

University of San Francisco, cavanaught@usfca.edu

Follow this and additional works at: http://repository.usfca.edu/phil

Part of the Philosophy Commons

\section{Recommended Citation}

Cavanaugh, Thomas A., "A Critique of the U.S. Genetic Privacy Act" (2002). Philosophy. Paper 21.

http://repository.usfca.edu/phil/21

This Article is brought to you for free and open access by the College of Arts and Sciences at USF Scholarship: a digital repository @ Gleeson Library | Geschke Center. It has been accepted for inclusion in Philosophy by an authorized administrator of USF Scholarship: a digital repository @ Gleeson

Library | Geschke Center. For more information, please contact repository@usfca.edu. 


\section{A CRITIQUE OF THE U.S. GENETIC PRIVACY ACT}

\section{Final draft post-refereeing}

Technology and Society, 21:3, Fall, 2002, 3.

T. A. Cavanaugh, Ph.D., University of San Francisco, Dept. of Philosophy cavanaught@usfca.edu

The Genetic Privacy Act is a proposal for U.S. Federal legislation funded by the Ethical, Legal and Social Implications of the Human Genome Project (ELSI) of the U.S. Department of Energy. The Act proposes to "protect the genetic privacy of individuals." The Act admirably safeguards the privacy of individuals from whom genetic information is gathered ("the sample source" ). It fails, however, to protect the privacy of others genetically related to the sample source. For example, the Act does not prevent a sibling - with informed consent and entirely voluntarily from giving a DNA sample to an insurance company in order to gather information on a brother or sister.

With the mapping of the Human Genome going hand-in-hand with the development of genetic testing, the importance of genetic information dramatically increases. Legislation is needed to structure the gathering and the dissemination of genetic information. Genetic information contains predictors of diseases and genealogical information such as paternity. As the authors of the Act note, if genetic information were obtained:

[B]y someone else without the individual's permission, another person could learn intimate details about the individual's likely future life. ... There are many people, including insurers and employers, to whom information about an individual's likely health future would be useful. 
The Act proposes federal legislation to insure that genetic information gathered from an individual is used only with the informed consent and written authorization of that individual. As the authors note:

[N]o stranger should have or control identifiable DNA samples or genetic information about an individual unless that individual specifically authorizes the collection of DNA samples for the purpose of genetic analysis, authorizes the creation of that private information, and has access to and control over the dissemination of that information.

The Act safeguards the privacy of the sample source. For example, the Act proposes that genetic information will not be gathered without the written consent of the sample source; that the nature of such information will be explained to the sample source; that the sample source has the right to have the sample of DNA destroyed; and so on. With respect to the protections offered by the Act for the privacy of the sample source, there is little to criticize. However, a significant lacuna arises when one analyses it from the standpoint of the privacy of those genetically related to the sample source. For, the Act offers little, if any, protection. In this respect, the Act fails to confront the unique nature of genetic information.

Although genetic information must always be gathered from one individual, its import reaches beyond that individual. Indeed, in some cases, the information gathered has greater significance for others than it has for the sample source. For example, in the case of a child, the results from my test, when coupled with those from my spouse may be determinative concerning whether or not my child has a genetic disease. This information concerning my child, in turn, is of great interest to insurance companies and employers. Thus, the privacy of genetic information is 
relevant not only for the sample source, but for many other individuals. The Act must take into account not only the privacy of the sample source, but also that of genetically related others.

One reasonable way of dealing with the unique character of genetic information is to make the information gathered as individualized as possible. By individualizing the information (e.g., not recording siblings, parents, offspring), genetic information can be made to resemble consent, which is individualized. In this way, one can attempt to respect the wishes of those who do not want to know, or who do not want others (insurance companies, employers) to know their genetic status, but who are genetically related to someone who does want to have this information gathered and recorded. Thus, if one records the information in as individualized a manner as possible, one will render the information recorded as individual as the consent that legitimates the gathering and recordation. To the extent to which the information is rendered individualized, the discrepancy between the group-import of genetic information and the individualized character of consent can be reduced and rendered less legally and ethically problematic. This is the principle of information individualization, or the PII. In accordance with the PII, one would not, for example, create a database of genetic and genealogical information without the consent of all. For in such a case, there would be too great a gap between the individualized character of consent and the group-character of the information recorded.

To balance out the greater value accorded by the Act to individuals' claims to know their genetic status over the claims of others whose status will be revealed and who do not want information gathered and recorded, one should have access to genetic information bearing upon oneself, regardless of the source of that information. That is, if one's sibling may without one's consent have genetic information gathered and recorded that bears upon oneself, then one should be granted access to any information that is linked to one's own record, regardless of the fact that 
another was the sample source. This will also help insure that the PII is followed. If it is not, the individual will at least know that it has been breached. Thus, if one's sibling has a genetic test, one has no claim to know the results, as long as those results, in accordance with the PII, never are linked with one's own information.

Moreover, the Act must explicitly recognize that consent is essentially individualized; that is, one can consent only for oneself (or as a surrogate for the incompetent.) One may not consent to give genetic information from oneself to determine the genetic status of a competent non-consenting genetically related individual. The Act must explicitly rule out such cases.

Thomas A. Cavanaugh, Ph.D.

Associate Professor

Philosophy

University of San Francisco 